\title{
PENGARUH IMPLEMENTASI CORPORATE SOCIAL RESPONSIBILITY (CSR) TERHADAP CITRA PERUSAHAAN (Studi pada PT. Semen Indonesia (Persero), Tbk.)
}

\author{
*( Mohammad Yaskun ${ }^{1}$, Puguh Cahyono ${ }^{2}$ \\ Prodi Manajemen, Fakultas Ekonomi, Universitas Islam Lamongan \\ $\mathrm{Jl}$. Veteran No.53A Lamongan \\ Telp. ( 0322 ) 324706, Faks. ( 0322 ) 324706 \\ Email:jpim.unisla@gmail.com
}

\begin{abstract}
ABSTRAK
Tujuan dari penelitian ini adalah untuk mengukur faktor-faktor yang ada dalam implementasi CSR yang dilakukan oleh PT. Semen Indonesia (Persero), Tbk. yang berpengaruh terhadap citra perusahaan bagi pihak inetrnal dan eksternal perusahaan (masyarakat yang merasakan dampak langsung keberadaan PT. Semen Indonesia (Persero), Tbk.). Hasil penelitian ini dari uji statistik yang telah dilakukan terhadap hipotesis awal penelitian, hanya $X_{7}$ (sektor sarana umum) berpengaruh signifikan secara negatif terhadap citra perusahaan (berlawanan dengan dugaan awal penelitian). Sedangkan $X_{1}$ (program kemitraan), $X_{2}$ (sektor pendidikan), $X_{3}$ (sektor kesehatan), $X_{4}$ (sektor pelestarian alam), $X_{5}$ (sektor bencana alam), $X_{6}$ (sektor olahraga, seni dan budaya), dan $X_{8}$ (sektor sarana ibadah). Berdasarkan kajian lebih lanjut terhadap hasil uji statistik tersebut, terdapat fakta bahwa hanya $30 \%$ dana dari program CSR PT. Semen Indonesia yang disalurkan di Gresik sedangkan 70\%nya ada di di Tuban. Kurang maksimalnya sosialisasi dan publikasi atas program-program CSR Semen Indonesia sehingga responden tidak mendapakan informasi yang cukup mengenai program-program CSR tersebut. Pelaksanaan dari program-program CSR yang tidak merata sehingga manfaatnyapun hanya dirasakan sebagian masyarakat saja.
\end{abstract}

Kata kunci : Corporate Sosial Resposibility (CSR), citra perusahaan.

\section{PENDAHULUAN}

Menurut Steinmetz dalam Sutojo (2004), pencitraan perusahaan dapat diartikan sebagai pembentukan jati diri atau identitas perusahaan. Menurut Anggoro (2002:21) dalam Angga (2009) Perusahaan-perusahaan yang memiliki citra bagus, mempunyai ciri: hubungan yang baik dengan para pemuka masyarakat. Kedua, hubungan positif dengan pemerintah setempat. Ketiga, resiko krisis yang lebih kecil. Keempat, rasa kebanggaan dalam organisasi dan diluar organisasi. Kelima, saling pengertian didalam organisasi dan diluar organisasi, dan Keenam meningkatkan kesetiaan para staf perusahaan.
Pengaruh tanggung jawab sosial terhadap citra perusahaan menurut Grahame dalam Hardepp (2006:14) dalam Angga (2009) adalah: 1) kepercayaan dalam perusahaan; 2) menciptakan suatu ikatan emosional dan intelektual dengan karyawan; 3) target konsumen dan pemegang saham penting lainnya; dan 4) mempunyai kredibilitas perusahaan yang tinggi. Sehingga untuk dapat terbentuknya Citra dan efektivitas organisasi dapat ditingkatkan dengan melakukan tanggung jawab social Corporate Sosial Resposibility (CSR). Salah satu contoh perusahaan yang sudah menerapkan yaitu CSR adalah PT. Semen Indonesia (Persero)Tbk. 
PT. Semen Indonesia (Persero) Tbk, merupakan salah satu produsen semen ternama di Indonesia dan Asia Tenggara. Sebagai perusahaan yang berhubungan dengan kepentingan masyarakat, PT. Semen Indonesia (Persero) Tbk secara konsisten terus berupaya untuk maju sekaligus memberikan manfaat bagi kesejahteraan masyarakat dan lingkungan sekitarnya, terutama untuk menghindari isu-isu maupun sentimen negatif dari masyarakat yang terkait dengan dampak negatif yang timbul akibat kegiatan operasional perusahaan.

Berdasarkan uraian tersebut, penelitian ini melakukan pengujian secara empiris tentang "Pengaruh Implementasi Corporate Social Responsibilty (CSR) Terhadap Citra Perusahaan Studi Kasus Pada PT. Semen Indonesia (Persero) Tbk". Fokus penelitian ini adalah citra perusahaan berdasarkan karyawan dan masyarakat yang berada pada wilayah Ring I Gresik PT. Semen Indonesia (Persero) Tbk. Sehingga tujuan penelitian ini adalah mengukur faktorfaktor yang ada dalam implementasi CSR yang dilakukan oleh PT. Semen Indonesia (Persero), Tbk. yang berpengaruh terhadap citra perusahaan bagi pihak inetrnal dan eksternal perusahaan (masyarakat yang merasakan dampak langsung keberadaan PT. Semen Indonesia (Persero), Tbk.)

\section{LANDASAN TEORI}

\section{Pengertian Corporate Sosial Responsibility (CSR) \\ CSR Menurut ISO 26000} Tanggung jawab sebuah organisasi terhadap dampak-dampak dari keputusan-keputusan dan kegiatan kegiatannya pada masyarakat dan lingkungan yang diwujudkan dalam bentuk perilaku transparan dan etis yang sejalan dengan pembangunan berkelanjutan dan kesejahteraan masyarakat; mempertimbangkan harapan pemangku kepentingan, sejalan dengan hukum yang ditetapkan dan norma-norma perilaku internasional; serta terintegrasi dengan organisasi secara menyeluruh (draft 3, 2007). Berdasarkan pedoman ini, CSR tidaklah sesederhana sebagaimana dipahami dan dipraktikkan oleh kebanyakan perusahaan. CSR mencakup tujuh komponen utama, yaitu: the environment, social development, human rights, organizational governance, labor practices, fair operating practices, dan consumer issues (Nugraha: 2010).

\section{Citra Perusahaan}

Menurut Lawrence L.Steinmetz yang dikutip oleh Sutojo (2004), citra perusahaan diartikan sebagai persepsi masyarakat terhadap jati diri perusahaan. Sehingga citra perusahaan yang dimaksud dalam penelitian ini adalah persepsi seseorang terhadap perusahaan didasari atas apa yang mereka ketahui atau mereka kira tentang perusahaan yang bersangkutan Sutojo (2004).

\section{Hubungan antara CSR dan Citra Perusahaan}

Menurut survey yang dilakukan

oleh Environics International (Toronto) dalam Conference Board (New York) dan Prince of Wales Business Leader Forum (London) yang diungkapkan oleh Dewi (2005) dalam (Majid, 2011:29), bahwa 60\% dari 25.000 responden di 23 negara berpendapat bahwa tanggungjawab sosial perusahaan merupakan salah satu faktor pembentuk citra positif perusahaan. Menurut Susanto (2007:28) dalam (Majid, 2011:29), 
perusahaan yang menjalankan tanggung jawab sosialnya secara konsisten akan mendapatkan dukungan yang luas dari komunitas yang merasakan manfaat dari berbagai aktivitas yang dijalankannya. Sehingga dapat disimpulkan CSR akan meningkatkan citra perusahaan dan dalam waktu yang panjang akan terakumulasi menjadi reputasi perusahaan.

Variabel independen dalam penelitian ini adalah program-program CSR yang telah dilakukan PT. Semen Gresik (Persero) Tbk diantaranya yakni (1) Program Kemitraan, Pendidikan, (3) Kesehatan, Pelestarian Alam, (5) Bencana A (6) Olahraga Seni dan Budaya, (7) Sarana Umum, (8) Sarana Ibadah. Variabel dependen dalam penelitian ini adalah Citra Perusahaan yang dapat diukur dari: (1) Kesediaan turut memikul tanggung jawab social, (2) Sejarah atau riwayat hidup perusahaan yang gemilang, (3) Reputasi sebagai pencipta lapangan pekerjaan dalam jumlah besar, (4) Komitmen mengadakan riset (Indarwati 2007:14) dalam (Ulva 2012:33).

Terdapat batasan pada pengukuran terhadap variabel pada penelitian ini. Adapun batasan tersebut sebagai berikut :

1) Pengukuran Implementasi Akuntansi Sosial (CSR) pada penelitian ini hanya pada dimensi Community Development yakni Program Kemitraan, Pendidikan, Kesehatan, Pelestarian Alam, Bencana Alam, Olahraga Seni dan Budaya, Sarana Umum dan Sarana Ibadah

2) Citra dalam penelitian ini berarti nilai perusahaan didalam persepsi masyarakat sekitar perusahaan berada melalui program-program Akuntansi Sosial (CSR) Community
Development yang dilakukan oleh perusahaan.

\section{METODE PENELITIAN DAN PEMBAHASAN}

Jenis Penelitian ini menggunakan penelitian kuantitatif. Untuk dapat melakukan pengukuran, setiap fenomena social di jabarkan kedalam beberapa komponen masalah, variable dan indikator (Sumanto:1995). Adapun teknik analisis data yang digunakan adalah regresi linear berganda dengan menggunakan SPSS 16.0 .

Populasi dalam penelitian ini adalah karyawan PT. Semen Indonesia dan masyarakat yang berada pada wilayah Ring I Gresik PT. Semen Indonesia (Persero), tbk. meliputi 3 kecamatan yakni Kecamatan Kebomas, Kecamatan Gresik dan Kecamatan Manyar Kabupaten Gresik Jawa Timur. Sampel penelitian terbagi menjadi pihak internal dan eksternal PT. Semen Indonesia (Persero), Tbk. Pihak Intern adalah karyawan PT. Semen Indonesia (Persero), Tbk. sebanyak 20 orang. Pihak Ekstern adalah 60 masyarakat kecamatan Kebomas, 20 masyarakat kecamatan Gresik dan 10 masyarakat kecamatan Manyar.

Tabel 1. Demografi Responden

\begin{tabular}{|l|l|}
\hline Keterangan & Frekuensi \\
\hline Jumlah Sampel & 100 \\
\hline Jenis Kelamin : & \\
Laki-laki & 55 \\
Perempuan & 45 \\
\hline Pendidikan : & \\
SD & 8 \\
SMP & 12 \\
SMA & 24 \\
D3 & 15 \\
S1 & 37 \\
S2 & 4 \\
\hline
\end{tabular}




\begin{tabular}{|l|l|}
\hline Pekerjaan : & \\
Karyawan & 18 \\
PNS & 20 \\
Wiraswasta & 32 \\
Petani & 12 \\
Dll & 18 \\
\hline
\end{tabular}

Sumber : Kuesioner penelitian, 2014.

Variabel dalam penelitian ini diukur dengan menggunakan skala likert 4. Hal ini dipilih berdasarkan karakteristik responden menghindari jawaban "aman" di titik tengah. Setiap item pertanyaan dalam penelitian ini telah diuji validitas dan reabilitasnya. Hasil uji validitas menunjukkan bahwa seluruh item pertanyaan dalam kuesioner mempunyai item-total correlation > 0,165 maka dapat disimpulkan bahwa seluruh item pertanyaan dalam kuesioner adalah valid. Berdasarkan hasil yang diperoleh dari pengujian reliabilitas instrumen penelitian, menun-jukkan cronbach's alpha > 0,60 maka dapat disimpulkan bahwa instrumen penelitian tersebut dinyatakan reliable.

\section{Hasil Pengujian Statistik}

Pengujian ini dilakukan dengan memperhatikan nilai $t$ hitung dari hasil regresi tersebut untuk mengetahui pengaruh variabel independen secara parsial terhadap variabel dependen dengan tingkat signifikansi pada alpha 5\%. Pengujian ini digunakan untuk menentukkan apakah ada pengaruh yang signifikan antara program kemitraan, sektor pendidikan, sektor kesehatan, sektor pelestarian alam, sektor bencana alam, dan sektor seni budaya dan olahraga, sarana umum dan sarana ibadah terhadap citra perusahaan.

Adapun metode dari penentuan $t$ tabel menggunakan ketentuan tingkat signifikansi $5 \%$ dengan $d f=\mathrm{n}-\mathrm{k}-1$ $(d f=100-8-1=91)$, sehingga didapat nilai $t$ tabel tinv $=(0.05,91)=$
1.986. Berdasarkan hasil pengujian disimpulkan hanya variabel sektor sarana umum (X7) secara statistik signifikan mempengaruhi citra perusahaan $(\mathrm{Y})$.

Tabel 2. Uji Regresi Berganda

\begin{tabular}{|c|c|c|c|c|c|c|}
\hline & & & Coeffi & icients $^{\mathrm{a}}$ & & \\
\hline & & $\begin{array}{r}\text { Unstan } \\
\mathrm{e} \\
\text { Coeffi }\end{array}$ & $\begin{array}{l}\text { dardiz } \\
\text { d } \\
\text { cients }\end{array}$ & $\begin{array}{c}\text { Standardi } \\
\text { zed } \\
\text { Coefficie } \\
\text { nts }\end{array}$ & & \\
\hline & & B & $\begin{array}{l}\text { Std. } \\
\text { Error }\end{array}$ & Beta & $\mathrm{t}$ & Sig. \\
\hline 1 & $\begin{array}{l}\text { (Con } \\
\text { stant } \\
)\end{array}$ & $\begin{array}{r}18.30 \\
9\end{array}$ & 1.870 & & 9.789 & .000 \\
\hline & $\mathrm{X} 1$ & .089 & .090 & .155 & .991 & .324 \\
\hline & $\mathrm{X} 2$ & -.036 & .131 & -.040 & -.271 & .787 \\
\hline & X3 & -.068 & .061 & -.147 & -1.105 & .272 \\
\hline & $\mathrm{X} 4$ & .111 & .150 & .137 & .738 & .462 \\
\hline & $\mathrm{X} 5$ & -.124 & .098 & -.134 & -1.270 & .207 \\
\hline & X6 & -.117 & .196 & -.130 & -.598 & .551 \\
\hline & $\mathrm{X} 7$ & -.433 & .154 & -.440 & -2.809 & .006 \\
\hline & $\mathrm{X} 8$ & .238 & .128 & .203 & 1.869 & .065 \\
\hline & $\begin{array}{l}\text { Dep } \\
\text { ble: }\end{array}$ & ndent & & & & \\
\hline
\end{tabular}

Sumber: Hasil pengolahan SPSS 2014.

Dari perhitungan regresi linier berganda dengan menggunakan SPSS 16, maka didapat hasil persamaan regresi sebagai berikut:

$$
\begin{aligned}
\mathrm{Y}= & 18,309+0,089 \mathrm{X}_{1}-0,036 \mathrm{X}_{2}- \\
& 0,068 \mathrm{X}_{3}+0,111 \mathrm{X}_{4}-0,124 \mathrm{X}_{5}- \\
& 0,117 \mathrm{X}_{6}-0,433 \mathrm{X}_{7}+0,238 \mathrm{X}_{8}+ \\
& \mathrm{e} .
\end{aligned}
$$

Dalam penelitian ini koefisien mengguakan nilai adjusted $\mathrm{R}^{2}$ bernilai sebesar 0,147. Yang berarti 14,7\% variabel bebas dapat menjelaskan variabel terikatnya sedangkan sisanya $85,3 \%$ dijelaskan oleh variabel lain diluar model. Berikut adalah tabel koefisien determinasi: 
Tabel 3.

\begin{tabular}{|c|c|c|c|c|}
\hline \multicolumn{5}{|c|}{ Model Summary } \\
\hline Model & $\mathrm{R}$ & $\begin{array}{l}\text { R } \\
\text { Squar } \\
\text { e }\end{array}$ & $\begin{array}{l}\text { Adjusted } \\
\text { R Square }\end{array}$ & $\begin{array}{l}\text { Std. } \\
\text { Error of } \\
\text { the } \\
\text { Estimate }\end{array}$ \\
\hline 1 & $.465^{\mathrm{a}}$ & .216 & .147 & 1.30766 \\
\hline
\end{tabular}

\section{HASIL PENELITIAN DAN PEMBAHASAN}

Berdasarkan pengujian yang telah dilakukan pada penelitian ini, peneliti melakukan kajian lebih lanjut khususnya pada variabel-variabel yang tidak memenuhi signifikansi secara statistik. Adapun hasil kajian tersebut adalah:

1) Berdasarkan pengujian statistik, variabel Program Kemitraan $\left(X_{1}\right)$ tidak berpengaruh signifikan terhadap Citra perusahaan (Y). Hal ini menunjukkan bahwa program CSR sektor program kemitraan $\left(X_{1}\right)$ tidak memiliki peranan penting terhadap citra perusahaan. Setelah Peneliti menggali informasi, ternyata sosialisasi dan pelaksanaan mengenai program kemitraan lebih banyak dilakukan di Tuban, $70 \%$ dana dari program kemitraan, disalurkan di Tuban sementara sisanya $30 \%$ yang disalurkan untuk wilayah Gresik dan sekitarnya, sehingga pelaksanaan program kemitraan yang ada di Gresik tidak bisa optimal dan akibatnya hanya dirasakan oleh segelintir orang saja.

2) Program sektor pendidikan $\left(X_{2}\right)$ tidak berpengaruh signifikan terhadap citra perusahaan. Salah satunya adalah program pendidikan kewirausahaan dan pendidikan kepemudaan yang diselenggarakan SGF melalui Enterpreunership Development Center (EDC) dan Youth Development Center (YDP). Mayoritas masyarakat ring 1 tidak mengetahui adanya program pendidikan tersebut sehingga mereka tidak dapat merasakan manfaat dari adanya program tersebut.. Selain itu, sekolahsekolah formal yang dibuka oleh PT. Semen Indonesia hanyalah sebatas kewajiban persero terhadap Permen BUMN dan ini hanya menguntungkan segelintir orang saja terutama karyawan. Masyarakat biasa juga kurang tertarik untuk menyekolahkan anak-anaknya ke Sekolah yang dinaungi oleh SGF, mereka lebih tertarik untuk menyekolahkan anaknya di sekolah negeri karena sekolah yang dinaungi SGF juga bukan merupakan sekolah favorit/unggulan diwilayah Gresik.

3) Variabel sektor kesehatan $\left(X_{\mathbf{3}}\right)$ tidak berpengaruh signifikan terhadap CItra perusahaan (Y). Rumah sakit yang dibuka oleh Semen Indonesia lebih diprioritaskan untuk karyawan Semen Indonesia. Jadi masyarakat biasa mendapatkan fasilitas dan pelayanan yang tidak sama dengan karyawan. Program-program sektor kesehatan yang diselenggarakan Semen Indonesia di Gresik kurang terpublikasi sehingga tidak semua masyarakat mengetahui dan merasakan manfaat dari program ini.

4) Variabel sektor pelestarian alam $\left(\mathrm{X}_{4}\right)$ tidak berpengaruh signifikan terhadap citra perusahaan (Y). Masyarakat awam banyak yang tidak mengetahui adanya program CSR pelestarian alam karena kurangnya publikasi media terhadap kegiatan-kegiatan program pelestarian alam Semen Indonesia 
(Semen Gresik). Selain itu semen Indonesia tidak pernah melibatkan masyarakat biasa untuk ikut bersama dalam melaksanakan program ini. Program pelestarian alam banyak dilakukan di luar wilayah Ring 1 Gresik karena masyarakat wilayah ring 1 Gresik sudah tidak lagi merasakan dampak negatf dari proses produksi semen karena pabrik sudah berpindah di wilayah Tuban sehingga program ini banyak dilakukan di Tuban.

5) Variabel sektor bencana alam $\left(X_{5}\right)$ tidak berpengaruh signifikan terhadap citra perusahaan. Hal ini disebabkan karena kurangnya publikasi media terhadap kegiatan bantuan bencana alam yang dilakukan oleh Semen Indonesia, sehingga responden tidak mengetahui tentang adanya kegiatan CSR Sektor bencana alam yang dilakukan Semen Indonesia.

6) Sektor olahraga seni dan budaya $\left(\mathrm{X}_{6}\right)$ tidak berpengaruh signifikan terhadap citra perusahaan. Hal ini disebabkan karena program ini ditujukan pada club olahraga binaan yang rata-rata dibentuk berdasarkan hobi dari para karyawan. Sehingga manfaatnya tidak banyak dirasakan oleh masyarakat umum.

7) Sektor sarana umum $\left(X_{7}\right)$ berpengaruh signifikan secara negatif terhadap citra perusahaan (berlawanan dengan dugaan awal penelitian). Hal ini disebabkan karena responden tidak merasakan manfaat dari sarana umum yang dilakukan Semen Indonesia. Sarana umum yang ada di Wilayah Ring 1 sudah cukup baik karena ini adalah wilayah kota sehingga pemeberian bantuan sarana umum oleh Semen Indonesia tidak banyak dilakukan diwilayah ini. Dan ada anggapan pada masyarakat bahwa keberadaan Semen Indonesia diwilayahnya malah merusak sarana umum dikarenakan banyaknya aktivitas transportasi perusahaan pada tempat tinggalnya.

8) Sektor sarana ibadah $\left(X_{8}\right)$ tidak berpengaruh signifikan terhadap citra perusahaan. Hal ini disebabkan karena kurangnya informasi yang beredar di masyarakat tentang pemberian bantuan dari Semen Indonesia. hanya kalangan pemuka agama dan pengurus tempat ibadah yang mengetahui informasi ini. Hal ini disebabkan pemberian bantuan sarana ibadah yang dilakukan oleh Semen Indonesia untuk sektor sarana ibadah berdasarkan proposalproposal yang masuk ke perusahaan. Selain itu perayaan-perayaan hari besar keagamaan yang menggunakan dana dari CSR Semen Indonesia lebih banyak dirasakan oleh karyawan Semen Indonesia sendiri seperti Himpunan Keluarga Nasrani Semen Gresik (HKNSG).

\section{KESIMPULAN DAN SARAN}

\section{Kesimpulan}

Berdasarkan hasil uji statistik yang telah dilakukan terhadap hipotesis awal penelitian ini, hanya X7 (sektor sarana umum) berpengaruh signifikan secara negatif terhadap citra perusahaan (berlawanan dengan dugaan awal penelitian). Sedangkan X1 (program kemitraan), X2 (sektor pendidikan), X3 (sektor kesehatan), X4 (sektor pelestarian alam), X5 (sektor bencana alam), X6 (sektor olahraga, seni dan budaya), dan X8 (sektor sarana ibadah). Berdasarkan kajian lebih lanjut terhadap hasil uji statistik tersebut, terdapat fakta bahwa: 
1) Hanya $30 \%$ dana dari program CSR PT Semen Indonesia yang disalurkan di Gresik sedangkan $70 \%$ nya ada di di Tuban.

2) Kurang maksimalnya sosialisasi dan publikasi atas program-program CSR Semen Indonesia sehingga responden tidak mendapakan informasi yang cukup mengenai program-program CSR tersebut.

3) Pelaksanaan dari program-program CSR yang tidak merata sehingga manfaatnyapun hanya dirasakan sebagian masyarakat saja.

\section{Saran}

Berdasarkan hasil penelitian, saran bagi peneliti selanjutnya adalah sebagai berikut:

1) Memperbanyak jumlah sampel penelitian dan melanjutkan lokasi penelitian di Tuban, sehingga diharapkan tingkat generalisasi dari analisis akan lebih akurat.

2) Menguji variabel-variabel lain atau penggunaan proxy yang berbeda guna menemukan variabel yang berpengaruh terhadap citra perusahaan.

3) Dalam perencanaan program CSR, perlu melibatkan seluruh aspek masyarakat agar program-program yang dilakukan benar-benar bermanfaat dan tepat guna bagi masyarakat dan lingkungan.

\section{DAFTAR PUSTAKA}

Ayu, Dyah. S. 2011. Pengaruh Implementasi Corporate Social Responsibility Terhadap Kesejahteraan Hidup Masyarakat (Studi Kasus Pada Pt. Apac Inti Corpora, Bawen). Karya Ilmiah. Semarang: Universitas Diponegoro.

Ali Darwin. 2004. Penerapan Sustainabilty Reporting di Indonesia, Konvensi Nasional
Akuntansi V, Program Profesi Lanjutan. Yogyakarta.

Bedjo, Bing Tanudjaja. 2006. Perkembangan Corporate Social Responsibility Di Indonesia. Nirmana Vol 8, No.2,Juli 2006: 92-98

Bewley. 2008. The Impact of A Change in Regulation on Environmental Disclosure: SAB92and the US Chemical Industry ". Issues in Social and Enviromental Accounting . Vol. 2,No. 1, June 2008 , pp. $61-88$.

Cristina, Astri Sihombing. 2011. Corporate Social Responsibility Dan Citra Perusahaan (Studi Korelasional Pengaruh Implementasi Program Corporate Social Responsibility terhadap Citra Perusahaan PT. Toba Pulp Lestari,Tbk pada Masyarakat di Kecamatan Parmaksian Toba Samosir). Karya Ilmiah. Medan: Universitas Sumatra Utara

Deegan, Craig. 2004. Financial Accounting Theory. Australia: McGraw-HillMahoney.

Erwin, Muhammad. 2011. Pengaruh Corporate Social Responsibility Terhadap Citra Perusahaan Pada PT. Telekomunikasi Indonesia, Tbk. Area Makassar. Karya Ilmiah. Makasar: Universitas Hasanudin.

Friwanti, Sonita N. 2010. Corporate Social Rsponsibility (CSR) dan Citra Perusahaan (Studi Korelasional mengenai Program CSR Bakti Olahraga PT Djarum terhadap Peningkatan Citra Perusahaan di Kalangan 
Mahasiswa USU). Karya Ilmiah.

Medan: Universitas Sumatra Utara

Harahap, Sofyan Safri. 1993. Teori Akuntansi, edisi satu, cetakan kedua, Penerbit Rajawali Press: Jakarta.

Hasyim, dan Rina Anindita. 2009. Prinsip-Prinsip Dasar Metode Riset Bidang Pemasaran. Jakarta: UIEU-University Press.

Hendriksen, Eldon S. dan Michael F. Van Breda. 2002. Teori Akunting. Terjemahan oleh Herman Wibowo. Buku 2. Edisi Kelima. Jakarta : Interaksara.

Ikatan Akuntan Indonesia. 2009. Standar Akuntansi Keuangan.Jakarta: Salemba Empat.

Exposure Draft Pernyataan Standar Akuntansi Keuangan XX. Akuntansi Lingkungan. Juli 2005.

Jefkins, Frank. 2004. Public Relations edisi kelima. Erlangga. Jakarta.

Kholis, Azizul. 2002. Tinjauan Teoritis Akuntansi Sosial (Social Accounting) dan Penerapannya di Indonesia. Media Riset Akuntansi, Auditing dan Informasi Vol 2 No 2 Agustus 2002 :27-43.

Kotler, Philip and Nancy Lee. 2005. Corporate Social Responsibility. New Jersey : John Wiley and Sons, Inc.

Lois, LaGore, W., dan Scazzero, J. A. 2008. Corporate Social Performance,Financial
Performance for Firm that Restate Earnings\|. Issues in Social and Enviromental Accounting. Vol. 2, No. 1, June 2008, pp. 104 130.

Majid, Paramita. 2012. Pengaruh Penerapan Corporate Social Responsibility Terhadap Citra Perusahaan Pada PT Hadji Kalla Cabang Sultan Alaudin Makasar. Karya Ilmiah. Makasar: Universitas Hasanudin.

Medley, Patrick. 1997. Environmental Accounting - What Does It Mean to Professional Accountants? Journal of Accounting Auditing $\&$ Accountability. Vol.10 No.4. pp. 594-600.

Menteri Hukum dan Hak Asasi Manusia Republik Indonesia. 2007. Undang-Undang Republik Indonesia Nomor 25, Tahun 2007 tentang Penanaman Modal.

2007. Undang-Undang Republik Indonesia Nomor 40, Tahun 2007 tentang perseroan Terbatas.

. 2007. Peraturan Menteri Badan Usaha Milik Negara Nomor PER-05/MBU/2007 tentang Program Kemitraan Badan Usaha Milik Negara dengan Usaha Kecil dan Program Bina Lingkungan.

. 2012. Peraturan Pemerintah Republik Indonesia Nomor 47, Tahun 2012 tentang tanggung jawab social dan lingkungan perseroan Terbatas.

Monika, Elisa. 2010. Pengaruh Implementasi Program 
Corporate Social Responsibility Beasiswa dan Citra Perusahaan (Studi Kasus Pengaruh Implementasi Program Corporate Social Responsibility Beasiswa Djarum Terhadap Peningkatan Citra Positif Perusahaan PT Djarum pada Mahasiswa USU). Karya Ilmiah. Medan: Universitas Sumatra Utara.

Permana, Angga. 2009. Pengaruh Corporate Social Responsibility Terhadap Citra Perusahaan Pada Sabun Mandi Lifebouy. Karya Ilmiah. Surabaya: Universitas Pembangunan Nasional "VETERAN" Jawa Timur.

Rakhmat, Jalaluddin. 2004. Metode Penelitian Komunikasi. Bandung: Remaja Rosdakarya.

Ramadhani, Rizky. 2011. Analisis Pengaruh Corporate Social Responsibility Terhadap Citra dan Loyalitas Konsumen PT Indosiar Visual Mandiri Tbk. Karya Ilmiah. Bogor: Institut Pertanian Bogor.

Rhenald, Kasali. 2003. Manajemen Public Relations. Jakarta: Grafiti, Remaja Rosdakarya. Bandung.

Singarimbun, Masri. 1995. Metode Penelitian Survei. Yogyakarta: PT.Pustaka LP3S Indonesia.

Suaryana Agung. Implementasi Akuntansi Sosial dan Lingkungan di Indonesia . Universitas Udayana.

Soemirat, Soleh; Ardianto Elvinaro. 2002. Dasar - Dasar Public Relations.
Sugyono. 2004. Statistik Non Parametrik. Bandung: Alfabeta.

Sumanto , 1995 , Metodologi Penelitian Sosial Dan Pendidikan, Yogyakarta : Andi Offset.

Sutisna. 2001. Perilaku Konsumen dan Komunikasi Pemasaran. Bandung: PT Remaja Rosdakarya.

Sutojo, Siswanto. 2004. Membangun Citra Perusahaan. Damar Mulia Pustaka. Jakarta.

Suyanto, Bagong dan Sutinah. 2005. Metode Penelitian Sosial: Berbagai Alternatif Pendekatan. Jakarta: Kencana.

Ulva. 2012. Analisis Pengaruh Corporate Social Responsibility (CSR) Terhadap Citra Perusahaan (Studi Kasus PT. International Nickel Indonesia, Tbk.). Karya Ilmiah. Makassar: Universitas Hasanuddin.

Widya, Wiwinda N. 2011. Penerapan Akuntansi Pertanggungjawaban Sosial Sebagai Bentuk Tanggungjawab Sosial Perusahaan (Corporate Social Responsibility) Terhadap Lingkungan Sekitarnya (Studi Kasus Pada Pt. Gudang garam, tbk). Karya Ilmiah. Surabaya:Universitas Narotama.

Yuni Nugraha. 2010. Corporate Social Responsibility Bukan Sekadar Tren dan Cost Center. http://yuninugraha.blogdetik.com /2010/12/01/corporate\%20social \%20responsibility/.diakses 25 Oktober 2012. 